\title{
Penile Cancer cN0 TNM Finding v7
}

National Cancer Institute

\section{Source}

National Cancer Institute. Penile Cancer cNO TNM Finding v7. NCI Thesaurus. Code C89187.

Penile cancer with no palpable or visibly enlarged inguinal lymph nodes. (from AJCC 7th Ed.) 